\title{
PSYCHE
}

VOL. XXX.

JUNE-AUGUST 1923

Nos. 3-4

\section{OCCURRENCE, LIFE-CYCLE, AND MAINTENANCE, UNDER ARTIFICIAL CONDITIONS, OF MIASTOR.}

\section{By Reginald G. Harris}

From the Laboratoire d'évolution des êtres organisés, Paris, Prof. Caullery, Director.

The genus Miastor is extremely interesting for several reasons. It was in this genus that paedogenesis was discovered by Nicholas Wagner in 1861. Though at first Wagner misinterpreted the phenomenon which he observed, and though his observations were doubted, subsequent investigation has demonstrated the fact of paedogenesis as well as the occurrence of polymorphism in this genus. But investigations upon Miastor have been limited, due to some extent at least, to the lack of a suitable method of maintaining the larvæ of this genus in the laboratory. Now that a method, which will be discussed later, has been found, it seems to the writer desirable to make a short resume of the occurrence of Miastor, its life cycle, and polymorphism among the larvæ of the genus.

\section{Occurrence of Miastor.}

Miastor larvæ were first observed underneath the bark of decaying trees. I have found them in France under the bark of decaying oak, chestnut, and birch logs, and in edible mushrooms.

Other observers have found Miastor larvæ in many kinds of decomposing wood and in fermenting beet pulp. It may be safely concluded that their occurrence is fairly widespread in decaying logs and that they are sometimes present in other vege- 
table matter. Their habitat is not limited to Europe. In America Felt ${ }^{1}$ found Miastor larvæ in 1910 under the partially decayed inner bark of chestnut rails.

In such environments Miastor larvæ usually occur in characteristic, compact, white colonial masses, a colony often containing a hundred or more individuals in close contact with each other. Among Miastor larvæ occurring in mushrooms I have not observed colonial arrangement. Here yellow or yellowish white larvæ are found singly although a single plant may contain many larvæ directly beneath the superficial cell-layers of the stalk or between the gills of the umbrella.

\section{The Life-Cycle of Miastor.}

Pædogenetic reproduction maintains in this genus during the autumn, winter, and spring, until the early summer, at which time pupæ occur, producing, after metamorphosis, male and female imagines. (The occurrence of pupæ, however, is not limited to the early summer. I have found them in nature in October, and in the same material pupæ continued to arise in the laboratory during the early winter. Though these were kept in conditions as natural as possible, at room-temperature, none of the pupæ has as yet given adults, though the usual period required for this metamorphosis in Miastor is about five days. Some of the pupæ have been destroyed by mould. It would seem that others, apparently in good condition, are in diapose.) The copulation of the adult flies results in the fertilization of the eggs which develop outside the mother into typical pædogenetic larvæ, and the cycle is complete.

Pædogenesis in Miastor is realized as follows: The ovaries of a typical pædogenetic larva produce eggs varying in number in different individuals, types and species. The development of larvæ from the eggs occurs within the body-cavity of the mother. The embryos continue to develop at the expense of the fatbodies, muscles and surrounding tissues of the mother larva until 
a suitable growth is attained. The embryos seem to be suitably developed, and are usually active for several days previous to their escape. At the time of escape, the larva, while not full grown, is well formed, active, and capable of continuing its existence. The time required for a typical pædogenetic generation is about two weeks, though the period varies with indivuals and environmental conditions. White pædogenetic larvæ produce four to ten or more embryos.

\section{Polymorphism in Miastor Larvœ.}

In all species of Miastor larvæ, which I have observed, there occur three distinct larval forms. Two are pædogenetic: viz. white and yellow pædogenetic larvæ, while the third is incapable of pædogenetic reproduction; it is the pupa-larva.

(1) Typical white podogenetic larvo.

The body of the larva contains fourteen segments. In the first or head-segment are the mouth opening and two antennæ. The mouth parts are arranged for sucking. The second and third segments contain the optic ganglia, and the third segment two eyes. In typical pædogenetic larvæ the eyes usually touch each other at their convex surfaces. The brain is in the fourth and fifth segments. Dorsal and partially posterior to it is the brain fat body. The salivary glands are in the fifth and sixth segments on either side of the œesophagus, their ducts opening in the mouth cavity. The osophagus extends posteriorly from the mouth and opens into the intestine in the fifth segment. In this region the intestine enlarges and folds, forming two blind appendices, which are in turn divided into two parts each. The digestive tube continues to enlarge slightly until it reaches the region of the tenth segment where it narrows into the rectum which is not functional in later stages. The intestine contains a peritropic membrane for inclosing undigested food. Four tubes of Malpighi extend anteriorly from the region of the twelfth to the tenth segment. The anus is in the fourteenth segment. Here are also two symmetrical anal flaps which are easily visible when protruded. The larva contains well developed fat-bodies, 
filling much of the body-cavity from the sixth to the fourteenth segments. The two ovaries occur in the region of the tenth segments, and are closely connected anteriorly with fat-bodies.

There are small chitinous points, arranged in four or more rows, extending around the larva between each segment from 2 to 14 . Six chitinous hooks terminate the larva in the last segment.

There are two tracheal trunks on each side of the body, one laterally ventral, one dorsal. These have numerous cross branches, viz., one large branch connecting the two dorsal trunks in each segment from 6 to 13 . From each of these branches two other minute branches extend posteriorly in each segment. Numerous branches and sub branches proceed from the ventral trunks. The dorsal and ventral trunks are connected in each segment from 6 to 13, another branch opening to the exterior on each side thus forming eight pairs of stigmata. There being no protruding spiracles it would seem difficult for the larvæ to remain long submerged. However, larvæ remain alive for long periods of time, a fortnight or more, when completely submerged in water under a cover-glass.

A series of large ganglia occur ventral to the digestive tube.

Locomotion results from stretching each segment and then contracting it, the process extending anteriorly. The rows of chitinous points prevent the larvæ from slipping.

The size of larvæ varies with species, individuals, cultures and age. New born pædogenetic larvæ of Miastor metraloas, average $1.35 \times 0.16 \mathrm{~mm}$, while pædogenetic mother-larvæ attain a length of from 3 to $4 \mathrm{~mm}$.

2) Yellow poedogenetic larvo.

Yellow forms (wanderers) are similar in general structure to white pædogenetic forms. They are extremely active. The body is usually slimmer, and the fat bodies less heavily developed than in white pædogenetic larvæ. The yellow pigment seems to occur for the most part in the fat-bodies. The eyes are noticeably larger than in other Miastor larval forms, and approach closely along their surfaces. 
Yellow larvæ usually produce but a single embryo in the species (Miastor metraloas?) which I found in decaying wood. Yellow larvæ (undescribed) occuring in mushrooms, however, produce a large number of embryos. I have frequently observed twenty embryos in a mother-larva.

Neither the role of, nor the incentive factor producing, yellow forms is clear.

In active yellow larvæ I have observed a jumping locomotion. This seems to occur as a result of the larva bending its body until the anal chitinous hooks catch against the chitinous points of the second or third segment. Extension of the segments then tightens the tension which finally breaks with a snap resulting in a jump. The yellow forms are extremely active, and may often be seen lifting their heads and much of their bodies straight into the air.

3) Pupa-larvo.

Larvæ which will metamorphose into pupæ are immediately distinguishable from other forms by means of three characteristic differences, though in general their structure is similar to that of white and yellow pædogenetic forms.

a) In newly born living pupa-larvæ the imaginal discs are visible. These occur laterally in the third, fourth and fifth segments. They are not present in pædogenetic forms.

b) The spathula sternalis, a structure typical of Cecidomyid larvæ, occurs ventrally in the third segment of the pupa-larvæ of Miastor. It is not visible in newly born living pupa-larvæ, but after four or five days becomes clearly visible, due to a yellowish coloration which later changes to orange and dark brown. The shape of this structure differs with various species. Its function is not understood.

c) The eyes of pupa-larvæ do not touch as in pædogenetic forms but are usually clearly separated.

The fat-bodies of pupa-larvæ are extremely well developed. The larvæ are active up to the time of pupation, unlike pædogenetic larvæ which of necessity become inactive with the progressive destruction of their muscles, due to the development of the embryos. 
In Miastor as in all cyclorrhaphous diptera, the pupa is formed within the last larval skin. After the pupa-larva comes to rest the color of its skin changes from white to yellow, later to orange red and dark brown.

Under optimum conditions a period of about five days is required for the metamorphosis of pupæ into imagines.

The causes which lead to the occurrence of the various types of larvæ within a single species of Miastor are not known. I have observed all the various types occurring side by side in nature and in the laboratory. Springer' $\mathrm{s}^{2}$ belief that the yellow forms and pupa-larvæ are produced by the action of light upon typical pædogenetic mothers does not seem tenable, since I have observed all types occurring in the laboratory in cultures reared in the dark as well as in those reared in the light.

\section{Method of Culture in the Laboratory.}

In order to carry on investigations concerning the factors regulating the life-cycle of Miastor and those causing polymorphism among the larvæ of a single species, it seemed immediately desirable to find a suitable artificial medium in which cultures might be reared in the laboratory under controlled conditions. With this in view I attempted to rear Miastor larvæ on various media, finally meeting with success on a mushroom bouillonagar innoculated with yeast.

The mushroom bouillon is made by taking equal parts by weight of mushrooms and water. The mushrooms are boiled in the water for 20-30 minutes. At the end of this time the mushrooms are withdrawn from the bouillon to which is added sufficient agar to make 4 per cent of the bouillon weight. The whole is heated until the agar is dissolved, when it is poured into small mouthed stock bottles stoppered with cotton, and sterilized; in this way the culture medium may be kept indefinitely. When it is needed for use, the medium is liquified in a hot water-bath and while still hot poured into culture dishes, and allowed to

2Springer, Fritz. Polymorphismus bei den Larven von Miastor metraloas. Zool. Jahrb Abth. f. Anst, vol. 40 p. 57 (1917). 
harden. For mass cultures of pædogenetic larvæ I have found petri dishes very suitable for culture containers. Since they allow but little loss by evaporation, the water of condensation falling back upon the culture medium, the medium remains moist, suitable for the reproduction of the yeast and the growth of the larvæ for some time. Larvæ may be more easily removed for examination from cultures reared in petri dishes than from those maintained in deep containers. Very small petri dishes may be used for individual cultures.

After the agar has hardened, a little powdered yeast is sprinkled over its surface, to which the larvæ are transferred. Cultures are then placed in the incubator at 20-22 degrees Centrigrade.

I have employed this culture medium for Miastor larvæ of various species, and have observed in colonies reared in this way all the larval forms occurring under natural conditions.

It seems then that a method has been found for rearing cultures of Miastor larvæ in the laboratory under conditions which may be easily regulated. This method should be suitable for maintaining cultures of a pædogenetic insect in the laboratory for class work as well as for carrying on investigations concerning the factors influencing the life-cycle and the polymorphism of the larvæ of Miastor. 

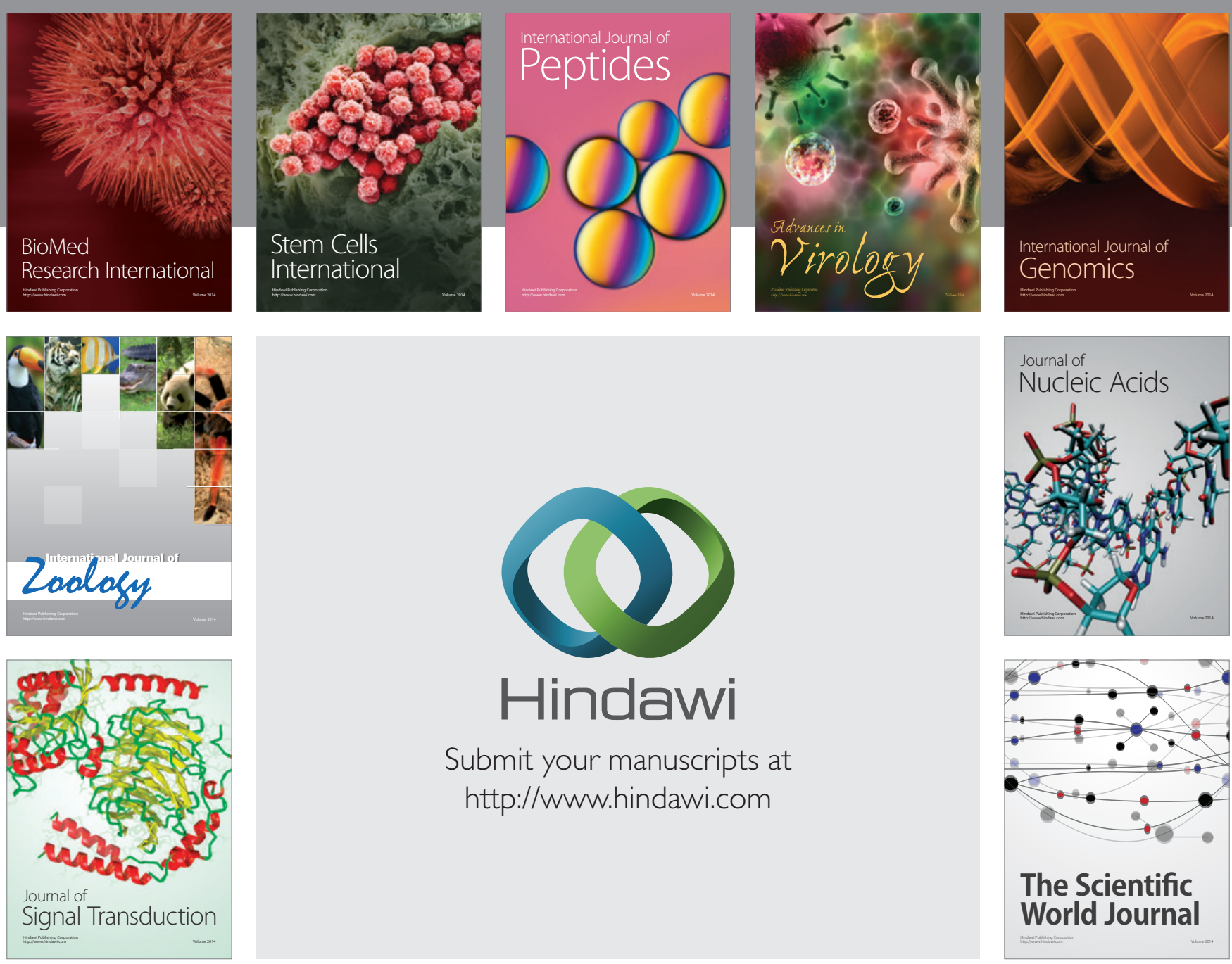

Submit your manuscripts at

http://www.hindawi.com
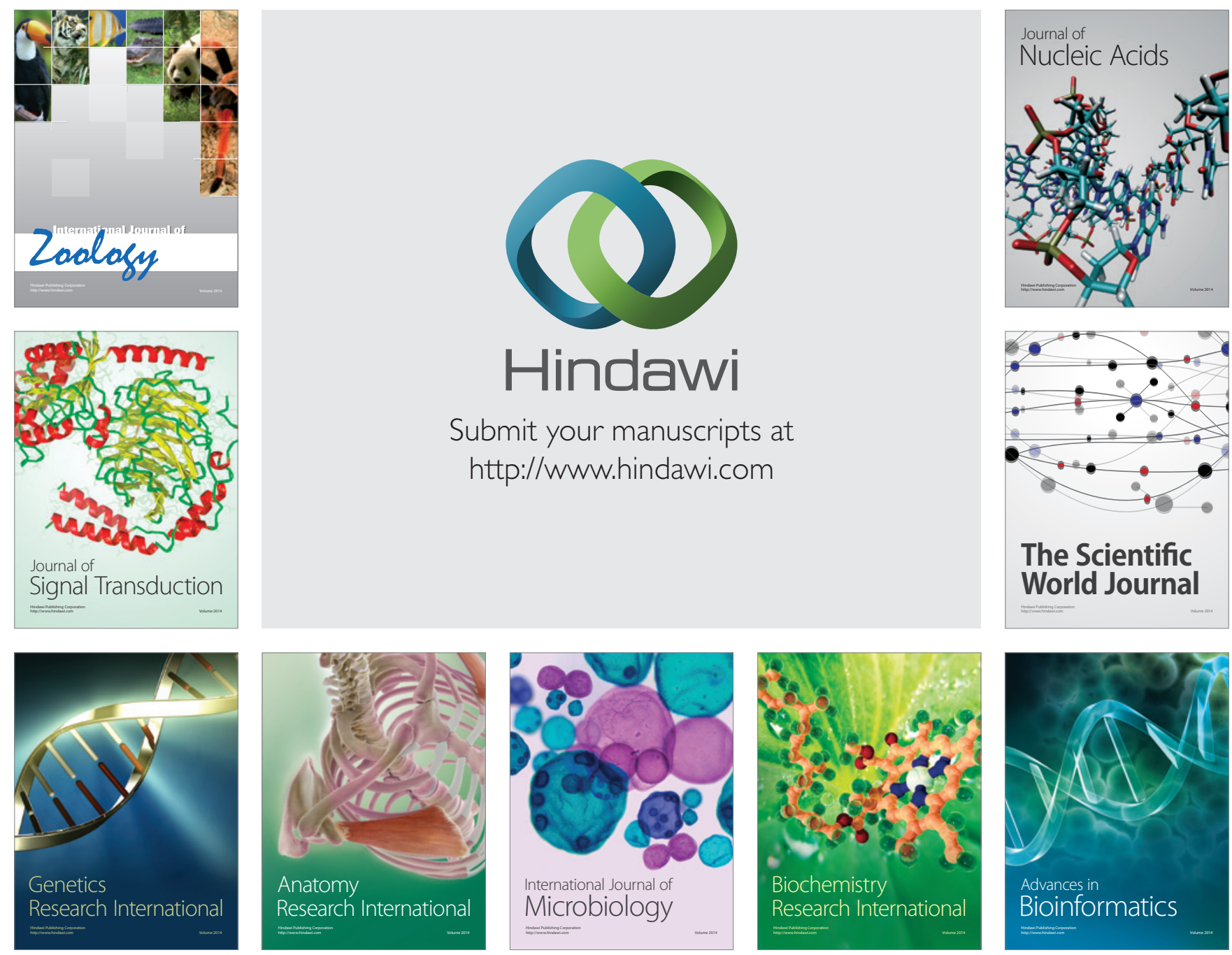

The Scientific World Journal
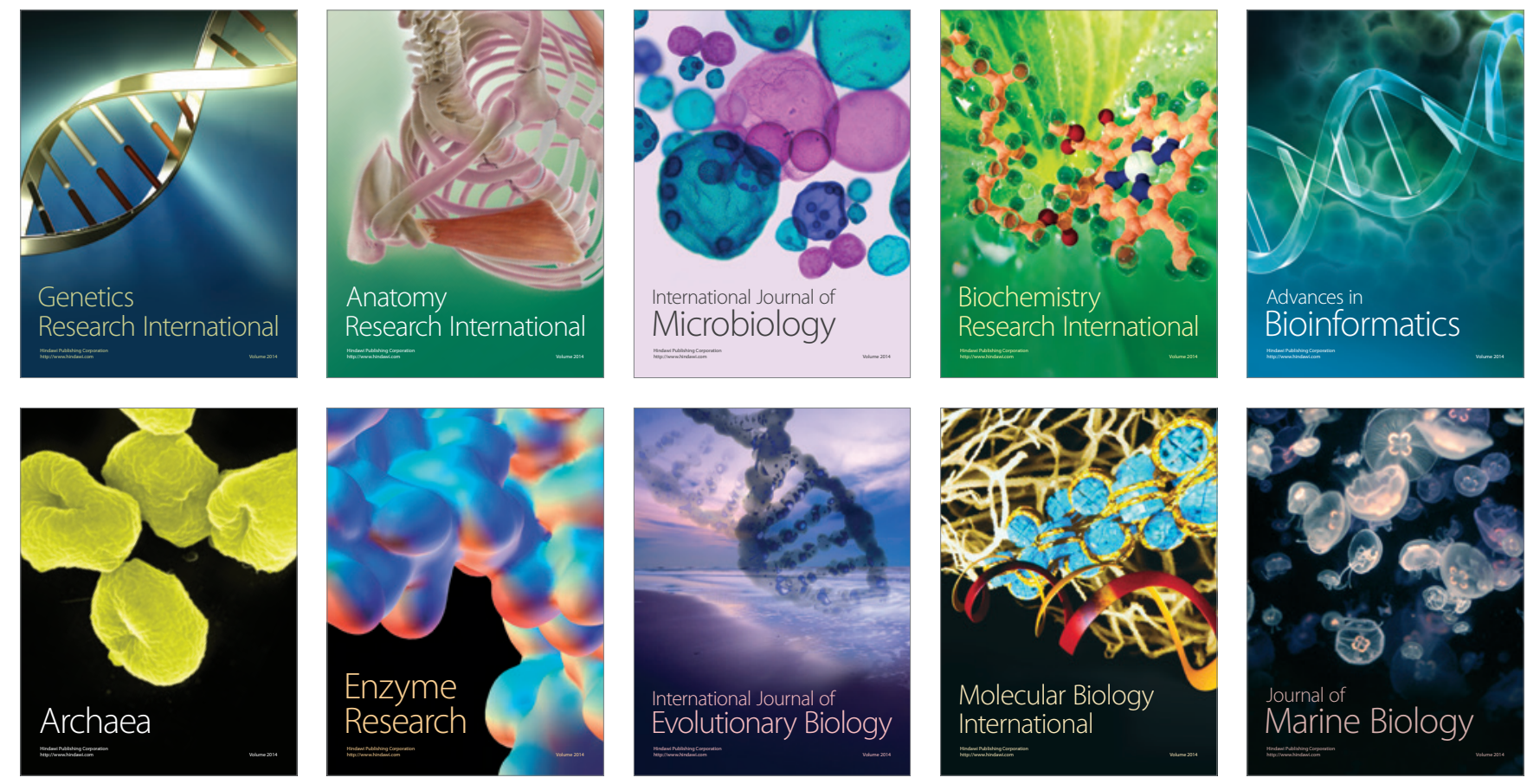